\title{
Thermal cracking products and bio-oil production from microalgae Desmodesmus sp.
}

\author{
Li Gang ${ }^{1}$, Xiang Shunan ${ }^{2}$, Ji Fang ${ }^{3}$, Zhou Yuguang ${ }^{4,5}$, Huang Zhigang ${ }^{1 *}$ \\ (1. School of Material Science and Mechanical Engineering, Beijing Technology and Business University, Beijing 100048, China; \\ 2. China Agricultural Machinery Testing Centre, Beijing 100122, China; 3. Chinese Academy of Agricultural Engineering, \\ Beijing 100125, China; 4. College of Engineering, China Agricultural University, Beijing 100083, China; \\ 5. Key Laboratory of Clean Production and Utilization of Renewable Energy, Ministry of Agriculture, Beijing 100083, China)
}

\begin{abstract}
Qualitative and quantitative analyses of thermal cracking products from Desmodesmus sp. were performed based on pyrolysis-gas chromatography-mass spectrometry (Py-GC/MS) at different temperature regimes $\left(350^{\circ} \mathrm{C}-750^{\circ} \mathrm{C}\right)$. After further analysis of a series of total ions chromatogram (TIC) and summarized, thermal cracking products of Desmodesmus sp. at different temperature regimes can be obtained, which mainly comprised of aliphatic hydrocarbons, nitrogen compounds, aromatic hydrocarbons, fatty acids, ketones, alcohols, aldehydes and furan compounds. Compared to bio-oil production at $650^{\circ} \mathrm{C}$ (32.07\%), Desmodesmus sp. pyrolyzed at $750^{\circ} \mathrm{C}$ could produce the highest bio-oil content of $42.25 \%$. However, higher temperature could lead to the formation of contaminants (nitrogen compounds and PAHs) more easily. Therefore, considering the higher content of bio-oil conversion and less pollutants generation, the optimum temperature for Desmodesmus sp. thermal cracking conversion was about $650^{\circ} \mathrm{C}$.
\end{abstract}

Keywords: microalgae, Desmodesmus sp., thermal cracking, bio-oil production, pyrolysis

DOI: $10.25165 /$ j.ijabe.20171004.3348

Citation: Li G, Xiang S N, Ji F, Zhou Y G, Huang Z G. Thermal cracking products and bio-oil production from microalgae Desmodesmus sp. Int J Agric \& Biol Eng, 2017; 10(4): 198-206.

\section{Introduction}

In the context of modern society, 'environment' and 'energy' are often in the opposite of the two sides that cannot coexist between each other. The consumption of fossil fuels doubles the $\mathrm{CO}_{2}$ content in the atmosphere, leading to climate change and causing serious environmental

Received date: 2017-04-07 Accepted date: 2017-05-26

Biographies: Li Gang, PhD, research interests: microalgae conversion and bioenergy, Email: ligang@btbu.edu.cn; Xiang Shunan, Engineer, research interests: biomass engineering, Email: xiangshunan17@163.com; Ji Fang, PhD, research interest: microalgae cultivation, Email: ji_fang1984@163.com; Zhou Yuguang, PhD, Associate Professor, research interests: bioenergy clean utilization, Email: zhouyg@cau.edu.cn.

* Corresponding author: Huang Zhigang, Professor, research interests: agricultural product processing engineering. School of Material Science and Mechanical Engineering, Beijing Technology and Business University, No. 11 Fucheng Road, Haidian District, Beijing 100048, China. Tel/Fax: +86-10-68985249; Email: huangzg@btbu.edu.cn. pollution. As a high-quality renewable energy, bio-crude oil is environmentally friendly, low- carbon emissions, etc. At present, the bio-fuel materials are mainly from oil plants, which account for the competition with food crops and higher costs of water and raw material, limiting the further promotion of bio-fuel applications. Due to the advantages of photosynthesis efficiency, short growth cycle, high-density large-scale production, and no occupying arable land resources, microalgae as a new bio-fuel raw material can effectively solve the problem of competition with food crops and raw materials costs, which will be the most potential to replace fossil fuels resources in the future ${ }^{[1]}$.

The research on the microalgae biomass conversion to biofuels began in the mid-1980s, when it focused on the use of microalgae to prepare biodiesel. However, this method required the microalgae with high oil content, and was highly impacted by the lipid composition and content $^{[2]}$. In order to make full use of microalgae 
biomass, some researches focused on pyrolysis of microalgae converted into bio-fuels, which has attracted a lot of attentions because of the higher bio-oil energy density, lower nitrogen and sulfur content, and easy preservation and transportation ${ }^{[3,4]}$. With the absence of oxygen or hypoxia conditions, the biomass are heated up to $500^{\circ} \mathrm{C}$ or higher temperature, the macromolecules of the biomass are cut off by thermal energy, and leading to the biomass structure isomerization and decomposing into small molecules through the whole pyrolysis process ${ }^{[5,6]}$. The products from the pyrolysis of biomass include gas, liquid and solid components. Pyrolysis can convert biomass into bio-char, bio-oil and syngas ${ }^{[4]}$.

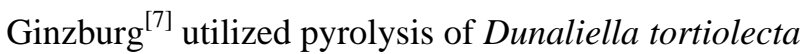
to obtain low sulfur, low nitrogen bio-oil firstly. Zhou et al. $^{[8]}$ conducted the pyrolysis experiment with Enteromorpha prolifera as raw material and found that the highest bio-oil yield (23.0\%) was obtained under conditions of temperature of $300^{\circ} \mathrm{C}$, reaction time of 30 min and addition of $5 \% \mathrm{Na}_{2} \mathrm{CO}_{3}$, and further analyzed the bio-oil components including substances such as fatty acids, aromatic hydrocarbons, olefins, esters, ketones, aldehydes, phenols and nitrogen-containing compounds. Minowa et al. ${ }^{[2]}$ studied the pyrolysis with Dunaliella tortiolecta as raw material. It was found that the biofuel content (37\%) was higher than that of the body (20.5\%) after the reaction at $340^{\circ} \mathrm{C}$ and $10 \mathrm{MPa}$ for $60 \mathrm{~min}$. It also showed that other components (proteins, carbohydrates, etc.) could be converted into bio-oils during the pyrolysis process. Furthermore, it was confirmed that the effects of temperature on the properties of bio-oils were significant, especially for bio-oils viscosity, calorific value, and the $\mathrm{C}, \mathrm{H}, \mathrm{O}$ element content. Ross et al. $^{[9]}$ studied the pyrolysis products from two kinds of low-fat microalgae Chlorella vulgaris and Sporulina sp. The results showed that high pyrolysis temperature and high fat content were beneficial to improve the yield of bio-oil that contained $70 \%-75 \%$ of carbon, $10 \%-16 \%$ of oxygen and $4 \%-6 \%$ of nitrogen; its composition included aromatic hydrocarbon compounds, long chain fatty acids, alcohol compounds and nitrogen compounds.

As a clean, environmentally friendly and renewable energy source, bioenergy will play a vital role in the sustainable development of mankind, and microalgae has been considered as one of the most promising biomass materials. The aim of this study was qualitative and quantitative analysis of thermal cracking products from Desmodesmus sp. at different temperature regimes, and explored the optimum conditions for the biofuels preparation by microalgae; and provided the scientific basis for the energy production and industrialization of microalgae biomass.

\section{Materials and Methods}

\subsection{Algae strain and culture condition}

Algae strain was a wild-type Desmodesmus sp., which was isolated from local river freshwater. It was preserved in BG11 medium and listed in Table 1. Algae were inoculated at 10\% (v/v) in $250 \mathrm{~mL}$ Erlenmeyer flasks containing $100 \mathrm{~mL}$ liquid medium. The culture flasks were incubated under stationary condition at $(25 \pm 2)^{\circ} \mathrm{C},(14 \mathrm{~h}: 10 \mathrm{~h})$ illumination period (light : dark) and $200 \mu \mathrm{mol} /\left(\mathrm{m}^{2} \cdot \mathrm{s}\right)$ continuous cool-white fluorescent light illumination.

Table 1 Chemical composition of BG11 medium

\begin{tabular}{ccc}
\hline No. & Chemicals & Concentration $/ \mathrm{g} \cdot \mathrm{L}^{-1}$ \\
\hline 1 & $\mathrm{NaNO}_{3}$ & 1.5 \\
2 & $\mathrm{~K}_{2} \mathrm{HPO}_{4}$ & $3 \times 10^{-2}$ \\
3 & $\mathrm{MgSO}_{4} \cdot 7 \mathrm{H}_{2} \mathrm{O}$ & $7.5 \times 10^{-2}$ \\
4 & $\mathrm{CaCl}_{2} \cdot 2 \mathrm{H}_{2} \mathrm{O}$ & $36 \times 10^{-2}$ \\
5 & Citric Acid combined with Ferric & $6 \times 10^{-3}$ \\
6 & $\mathrm{Ammonium} \mathrm{Citrate}$ & $6 \times 10^{-3}$ \\
7 & $\mathrm{EDTA}^{-3}$ & $1 \times 10^{-3}$ \\
8 & $\mathrm{Na}_{2} \mathrm{CO}_{3}$ & $6 \times 10^{-3}$ \\
\hline & $\mathrm{H}_{3} \mathrm{BO}_{3}$ & $2.86 \times 10^{-3}$ \\
& $\mathrm{MnCl}_{2} \cdot 4 \mathrm{H}_{2} \mathrm{O}$ & $1.81 \times 10^{-3}$ \\
& $\mathrm{ZnSO}_{4} \cdot 7 \mathrm{H}_{2} \mathrm{O}$ & $2.22 \times 10^{-4}$ \\
9 & $\mathrm{NaMoO}_{4} \cdot 5 \mathrm{H}_{2} \mathrm{O}$ & $3.9 \times 10^{-4}$ \\
& $\mathrm{CuSO}_{4} \cdot 5 \mathrm{H}_{2} \mathrm{O}$ & $7.9 \times 10^{-5}$ \\
& $\mathrm{Co}_{2}\left(\mathrm{NO}_{2}\right)_{2} \cdot 6 \mathrm{H}_{2} \mathrm{O}$ & $4.94 \times 10^{-4}$ \\
\hline
\end{tabular}

\subsection{Raw material and sample preparation}

Desmodesmus sp. was preserved in BG11 medium for $14 \mathrm{~d}$ and the culturing condition was described as 2.1. After $14 \mathrm{~d}$ of cultivation, algae cells were harvested by centrifugation at $10000 \mathrm{r} / \mathrm{min}$ for $10 \mathrm{~min}$ and dried by a vacuum freeze dryer (Savant Instruments Inc., USA), then stored at $4^{\circ} \mathrm{C}$ before being analyzed.

\subsection{Compositional analysis}

The carbon, hydrogen, nitrogen and sulfur contents in sample were measured using an elemental analyzer (Flash 
EA-1112, Thermo, USA) at the Institute of Chemistry, Chinese Academy of Sciences. Reported values were from the average of at least triplicate samples. The Bligh and Dyer method was used to determine the total lipid content of the sample ${ }^{[10]}$. It is indicated that the protein content (wt\%) of the sample equals 6.25 times of the nitrogen content of the sample $e^{[11]}$, referring to Equation (1).

Protein content $=$ Nitrogen $\times 6.25$

The Equations established below for high heating value (HHV) of sample was employed ${ }^{[12]}$.

$$
\begin{aligned}
& \text { HHV }(\mathrm{OLS})= 1.87 \mathrm{C}^{2}-144 \mathrm{C}-2082 \mathrm{H}+63.8 \mathrm{C} \times \mathrm{H}+ \\
& 129 \mathrm{~N}+20147 \\
& \mathrm{HHV}(\mathrm{PLS})= 5.22 \mathrm{C}^{2}-319 \mathrm{C}-1674 \mathrm{H}+38.6 \mathrm{C} \times \mathrm{H}+ \\
& 133 \mathrm{~N}+21028
\end{aligned}
$$

$\mathrm{C}, \mathrm{H}$ and $\mathrm{N}$ represent the content of carbon, hydrogen and nitrogen elements, respectively. Equations (2) and (3) were obtained respectively through regression analysis of ordinary least square (OLS) and partial least square (PLS) of high heating value for sample. According to the suggestions of Friedl et al. ${ }^{[13]}$, the mean value of $\mathrm{HHV}(\mathrm{MJ} / \mathrm{kg})$ was calculated according to Equation (4):

$$
\begin{aligned}
& \mathrm{HHV}=\frac{\mathrm{HHV}(\mathrm{OLS})+\mathrm{HHV}(\mathrm{PLS})}{2}=\left(3.55 \mathrm{C}^{2}-232 \mathrm{C}-\right. \\
& 2230 \mathrm{H}+51.2 \mathrm{C} \times \mathrm{H}+131 \mathrm{~N}+20600) \times 10^{-3}
\end{aligned}
$$

\subsection{Thermal cracking characteristics of sample}

The analyzer (Py-GC/MS) used for sample pyrolysis was composed by a pyrolysis device (Frontier Labs 3030i, Japan) and gas chromatography-mass spectrometer (GC/MS, Agilent 7890A/5975C, USA).

The Py-GC/MS real-time testing was performed between $350^{\circ} \mathrm{C}-750^{\circ} \mathrm{C}\left(100^{\circ} \mathrm{C}\right.$ for temperature interval) for the sample to obtain the total ion current (TIC) diagrams of sample pyrolysis product components. The analysis condition of GC refers to Table 2.

Table 2 Analytical condition of GC settings

\begin{tabular}{cc}
\hline Name & Parameters \\
\hline $\begin{array}{c}\text { Capillary column } \\
\text { The carrier gas } \\
\text { and flow rate }\end{array}$ & $\mathrm{HP}-5(30 \mathrm{~m} \times 0.25 \mathrm{~mm} \times 0.25 \mu \mathrm{m})$ \\
$\begin{array}{c}\text { Inlet temperature } \\
\text { Split ratio }\end{array}$ & He, $1.0 \mathrm{~mL} / \mathrm{min}$, constant current \\
$\begin{array}{c}\text { Temperature } \\
\text { programming }\end{array}$ & $5^{\circ} \mathrm{C} / \mathrm{min}$, keep 5 min; up to $250^{\circ} \mathrm{C}$ by $10^{\circ} \mathrm{C} / \mathrm{min}$, keep $5 \mathrm{~min}$. \\
\hline
\end{tabular}

\subsection{Bio-oil production from the sample}

The TIC diagrams of sample pyrolyzed products under different temperature conditions were obtained. Results were analyzed using Agilent MSD Productivity Chem Station for GC and GC/MS System Data Analysis application software (Version D 03.00.552, Agilent, USA). Retention time and peak area percentages of different compounds in pyrolyzed products were determined by comparing with NIST 2011 Database (Version 2.0, National Institute of Science and Technology, USA). The concentrations of each individual compound were of right proportion to its corresponding peak area percentage.

\section{Results and discussion}

\subsection{Composition analysis}

Table 3 lists the carbon, hydrogen, nitrogen and sulfur content, HHV values, lipid content, and protein content of the sample. Table 3 also shows the relevant data of Scenedesmus sp. and wheat straw for comparison ${ }^{[14,15]}$. The contents of carbon, hydrogen and nitrogen in sample were higher than that of Scenedesmus sp., especially carbon content, which was about 6\% higher than that of Scenedesmus sp. On the contrary, with compared to other biomass material (wheat straw), the sample was seen to have a lower content of carbon and higher of hydrogen and nitrogen. In the chemical analysis, the protein content of sample was much higher than that of Scenedesmus sp. due to its higher nitrogen content, sample lipid content was also higher than Scenedesmus sp. at the same time. In addition, the HHV of sample was found to be lower than wheat straw but higher than Scenedemus sp. It was reported that Scenedesmus sp. had a biofuel calorific value of $18.4 \mathrm{MJ} / \mathrm{kg}$ when pyrolyzed at $480^{\circ} \mathrm{C}^{[14]}$, while sample was higher than Scenedesmus sp. which indicated that sample could have a very large potential for energy production according to the above-mentioned analysis.

Table 3 Compositional analysis of feedstock

\begin{tabular}{ccccccccc}
\hline & \multicolumn{4}{c}{ Elemental analysis/\% } & & \multicolumn{2}{c}{ Chemical analysis/\% } \\
\cline { 2 - 4 } Feedstock & $\mathrm{C}$ & $\mathrm{H}$ & $\mathrm{N}$ & $\mathrm{S}$ & $\mathrm{MJ} \cdot \mathrm{kg}^{-1}$ & $\begin{array}{c}\text { Lipid } \\
\text { content }\end{array}$ & $\begin{array}{c}\text { Protein } \\
\text { content }\end{array}$ \\
\hline Sample & 38.05 & 6.30 & 7.67 & 0.56 & 16.14 & 16.6 & 47.94 \\
Scenedesmus sp. & 32.1 & 4.8 & 5.3 & 0.5 & 14.69 & 11.5 & 27.8 \\
Wheat straw & 44.93 & 5.71 & 0.63 & - & 17.83 & - & - \\
\hline
\end{tabular}




\subsection{Analysis of constitution of sample pyrolysis} products

The pyrolysis temperature is an important factor in the thermal cracking of biomass, and different cracking temperatures result in different degrees of thermal cracking $^{[16]}$. When the pyrolysis temperature rises to a certain extent, it will be accompanied by the secondary thermal cracking reaction; the primary part of the primary products of the pyrolysis product will undergo thermal cracking again to obtain the secondary cracking products ${ }^{[17]}$. Therefore, it is important to study the composition of pyrolysis products of biomass with pyrolysis temperature, which is of great significance to explore the process parameters of biomass pyrolysis.

Figure 1 showed the TIC diagram of sample pyrolyzed at $350^{\circ} \mathrm{C}$, specific components can be obtained after further analysis, which including 40 kinds of compounds such as hydrocarbons, acids, amides, alcohols and other organic substances. Among them, the relative content (more than 3\%) were 2,6,6-trimethylbicycloheptane (24.65\%), squalene (17.95\%), acetylhydrazine (4.12\%), 9-octadecenamide (4.02\%), heptadecane (3.72\%), 3,7,11,15-tetramethyl-2-hexadecene (3.48\%) and hexadecamide (3.14\%), and the retention time was $34.46 \mathrm{~min}, 48.29 \mathrm{~min}, 4.06 \mathrm{~min}, 46.24 \mathrm{~min}$, $31.44 \mathrm{~min}, 34.56 \mathrm{~min}$ and $43.42 \mathrm{~min}$, respectively.

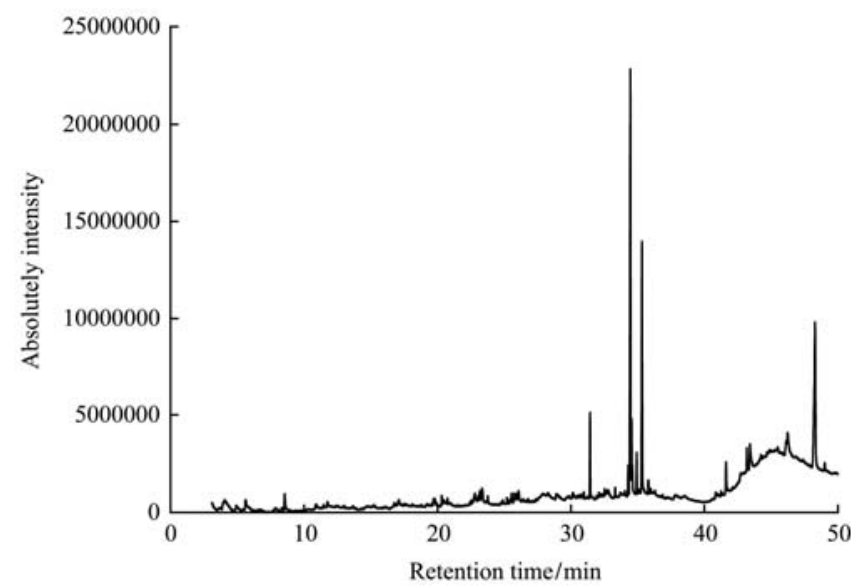

Figure 1 TIC diagram of sample pyrolytic bio-oil at $350^{\circ} \mathrm{C}$

As we can see from Figure 2, thermal cracking products of sample at $450^{\circ} \mathrm{C}$ included 111 compounds, among which more than $3 \%$ were 9-octadecyne (13.85\%), 1H-imidazole-4-propylamine (8.27\%), toluene (6.37\%), 6,10,14- (4.50\%), hexadecamide (3.44\%) and methyl-8,10,14-octadecynylmethyl ester (3.41\%).

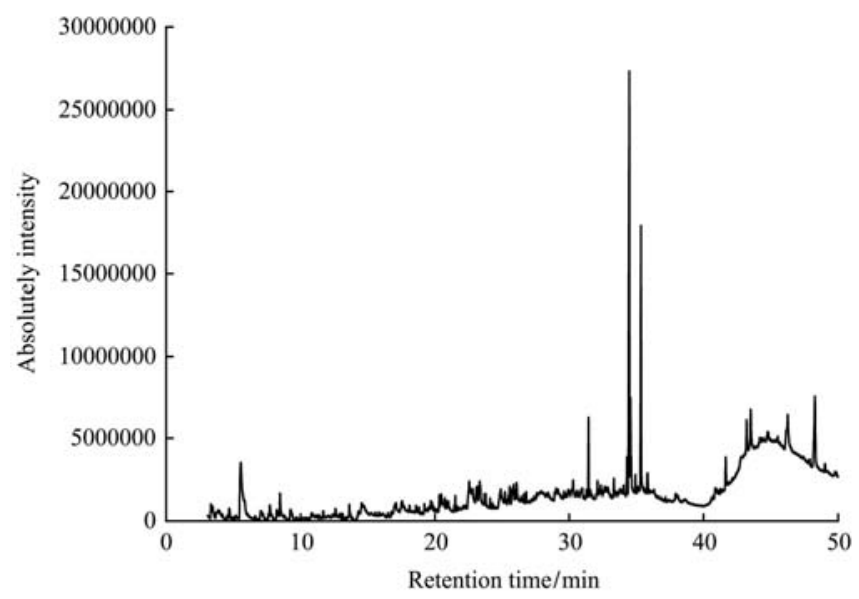

Figure 2 TIC diagram of sample pyrolytic bio-oil at $450^{\circ} \mathrm{C}$

After the similarly analysis from Figures 3, 4 and 5, and we can concluded that 111, 183 and 149 kinds of thermal cracking products can be obtained at $550^{\circ} \mathrm{C}$, $650^{\circ} \mathrm{C}$ and $750^{\circ} \mathrm{C}$ respectively. Each temperature generated different kinds of compounds, such as 9-octadecyne was the highest content at $550^{\circ} \mathrm{C}$, while toluene was the top at $650^{\circ} \mathrm{C}$ and $750^{\circ} \mathrm{C}$.

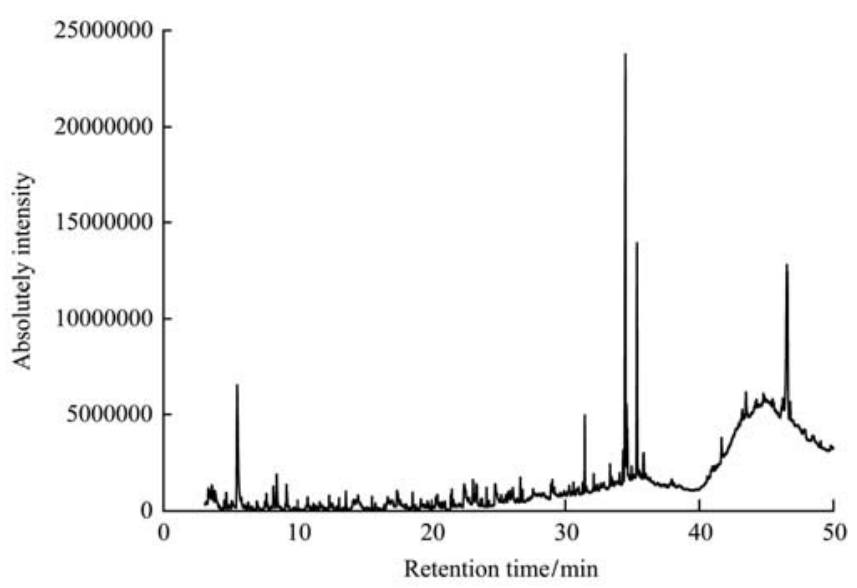

Figure 3 TIC diagram of sample pyrolytic bio-oil at $550^{\circ} \mathrm{C}$

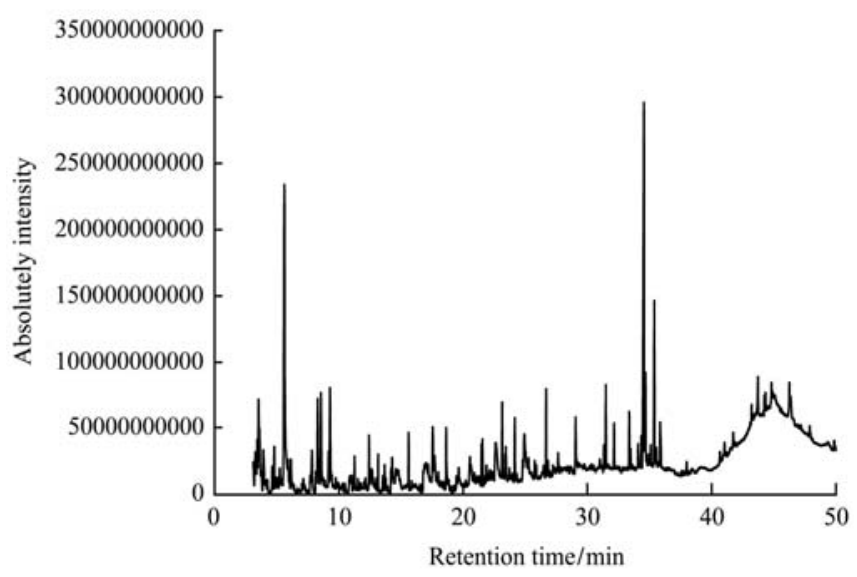

Figure 4 TIC diagram of sample pyrolytic bio-oil at $650^{\circ} \mathrm{C}$ 


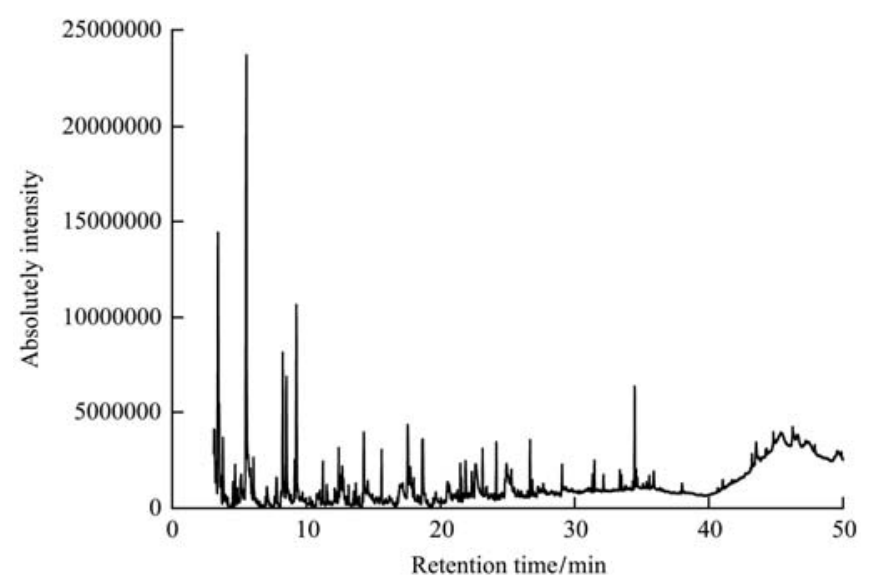

Figure 5 TIC diagram of sample pyrolytic bio-oil at $750^{\circ} \mathrm{C}$

\subsection{Analysis of bio-oil production of sample under different temperature}

In order to better study the bio-oil production of sample under different temperature, generally in accordance with the practice of analysis, only the pyrolysis products that matching degree larger than $80 \%$ were summarized and compared. After further analysis, thermal cracking products of sample were divided into the following categories: aliphatic hydrocarbons (alkanes and olefins), aromatic hydrocarbons (benzene, indene and derivatives thereof), acids, nitrogen compounds (amides, indoles and pyrimidines), polycyclic aromatic hydrocarbons (PAHs), ketones, alcohols, aldehydes, phenols, and furans. This conclusion was similar to that of other researchers ${ }^{[18,19]}$, and the relative peak areas of the various substances at different temperatures were listed in the following Tables.

Among the compounds listed in Tables 4, the aliphatic hydrocarbon compounds were mainly composed of alkanes and alkenes, which are natural constituents in fossil fuels. Aliphatic hydrocarbons are of great value in fuel applications and accompanied by temperature ${ }^{[19]}$. When the cracking temperature raised from $350^{\circ} \mathrm{C}$ to $450^{\circ} \mathrm{C}$, the relative content of the aliphatic hydrocarbon compounds decreased gradually; when the temperature raises from $450^{\circ} \mathrm{C}$ to $650^{\circ} \mathrm{C}$, the relative content of the aliphatic hydrocarbon compounds gradually increased and reached a maximum of $13.58 \%$ at $650^{\circ} \mathrm{C}$; when temperature raised from $650^{\circ} \mathrm{C}$ to $750^{\circ} \mathrm{C}$, the relative content of the aliphatic hydrocarbon compounds was gradually reduced, possibly due to the high temperature leading to the secondary reaction of the pyrolysis product.
Table 4 Effect of temperature on aliphatic hydrocarbons from sample pyrolyzed at $350^{\circ} \mathrm{C}-750^{\circ} \mathrm{C}$

\begin{tabular}{|c|c|c|c|c|c|c|}
\hline \multirow{2}{*}{ Groups } & \multirow{2}{*}{ Compounds } & \multicolumn{5}{|c|}{ Peak area percentage /\% } \\
\hline & & $350^{\circ} \mathrm{C}$ & $450^{\circ} \mathrm{C}$ & $550^{\circ} \mathrm{C}$ & $650^{\circ} \mathrm{C}$ & $750^{\circ} \mathrm{C}$ \\
\hline \multicolumn{7}{|l|}{ Aliphatics } \\
\hline \multirow{11}{*}{ Alkanes } & Cyclopropane, 1,2-dibutyl- & & & 0.23 & & \\
\hline & $\begin{array}{l}\text { Cyclopropane, } \\
\text { 1-methyl-2-pentyl- }\end{array}$ & & & 0.63 & & \\
\hline & $\begin{array}{c}\text { Cyclohexane, } \\
\text { 1-(1,5-dimethylhexyl)-4- } \\
\text { (4-methylpentyl) }\end{array}$ & & & 0.44 & & 0.91 \\
\hline & Propylidencyclohexane & & & & & 0.19 \\
\hline & Undecane, 2,6-dimethyl- & & & & 0.12 & \\
\hline & Tridecane, 7-methylene- & & & & 0.47 & 0.29 \\
\hline & Tridecane, 7-cyclohexyl- & & & & 0.024 & \\
\hline & Pentadecane & & & 0.34 & 0.28 & \\
\hline & Cyclopentadecane & & & & & 0.27 \\
\hline & Heptadecane & 3.72 & 1.81 & 1.60 & 1.05 & 0.39 \\
\hline & sum & 3.72 & 1.81 & 3.24 & 1.93 & 2.05 \\
\hline \multirow{21}{*}{ Alkenes } & $\begin{array}{c}\text { Cyclohexene, } \\
\text { 4-(4-ethylcyclohexyl)- } \\
\text { 1-pentyl- }\end{array}$ & & & 0.56 & & \\
\hline & 1-Heptene & & & & 1.11 & 1.18 \\
\hline & $\begin{array}{c}\text { Bicyclo[2.2.1]hept-2-ene, } \\
\text { 1-methyl- }\end{array}$ & & & & & 0.55 \\
\hline & 1-Octene, 3,7-dimethyl- & & & & 1.17 & 0.61 \\
\hline & 1-Nonene & & & & 0.48 & 0.55 \\
\hline & 1-Decene & & & 0.37 & 0.70 & 0.82 \\
\hline & 1-Undecene & & & & 0.71 & 0.76 \\
\hline & 1-Dodecene & & & & 1.32 & \\
\hline & 1-Tridecene & & & 0.19 & 0.45 & 0.46 \\
\hline & Bicyclo[10.1.0]tridec-1-ene & 0.30 & & & & \\
\hline & 1-Tetradecene & & & 1.00 & 0.79 & 0.85 \\
\hline & 2-Tetradecene, (E)- & & & & & 0.16 \\
\hline & 1-Pentadecene & & & 0.58 & 1.10 & 0.77 \\
\hline & $\begin{array}{l}\text { 2-Hexadecene, } \\
\text { 3,7,11,15-tetramethyl-, } \\
\text { [R-[R*,R*-(E)]]- }\end{array}$ & 4.94 & 3.24 & 2.53 & 1.46 & 0.25 \\
\hline & 1-Heptadecene & & & & 0.46 & \\
\hline & 3-Heptadecene, (Z)- & & & & & 0.23 \\
\hline & 8-Heptadecene & & & & 0.34 & \\
\hline & 1-Nonadecene & 0.92 & & 0.58 & 0.31 & 0.19 \\
\hline & 1-Eicosene & & & 0.29 & 0.88 & \\
\hline & D-Limonene & & 0.68 & & & \\
\hline & sum & 6.16 & 3.92 & 6.10 & 11.65 & 7.38 \\
\hline sum & & 9.88 & 5.73 & 9.34 & 13.58 & 9.43 \\
\hline
\end{tabular}

Aromatic hydrocarbon compounds are an important industrial chemical and can also be used as a fuel additive to improve the octane number and the quality of the fuel. In the thermal cracking products of sample, the aromatic hydrocarbon compounds were mainly composed of benzene, derivatives of benzenes and indenes. As it can be seen from Table 5, the aromatic hydrocarbon compounds increased as the cracking temperature raised between $350^{\circ} \mathrm{C}-750^{\circ} \mathrm{C}$, the relative content of the 
aromatic hydrocarbon compounds increased with the temperature, and finally up to the highest content $(32.62 \%)$ at $750^{\circ} \mathrm{C}$. It was also verified that high temperature above $550^{\circ} \mathrm{C}$ could produce a large amount of aromatic hydrocarbon compounds.

Table 5 Effect of temperature on aromatic hydrocarbons from sample pyrolyzed at $350^{\circ} \mathrm{C}-750^{\circ} \mathrm{C}$

\begin{tabular}{|c|c|c|c|c|c|c|}
\hline \multirow{2}{*}{ Groups } & \multirow{2}{*}{ Compounds } & \multicolumn{5}{|c|}{ Peak area percentage/\% } \\
\hline & & $350^{\circ} \mathrm{C}$ & $450^{\circ} \mathrm{C}$ & $550^{\circ} \mathrm{C}$ & $650^{\circ} \mathrm{C}$ & $750^{\circ} \mathrm{C}$ \\
\hline \multicolumn{7}{|l|}{ Aromatics } \\
\hline \multirow{14}{*}{ Benzenes } & Benzene & & & 0.73 & 1.70 & 5.43 \\
\hline & Benzene, propyl- & & & & & 0.80 \\
\hline & Benzene, 2-propenyl- & & & & & 0.59 \\
\hline & Benzene, 3-butenyl- & & & & & 0.18 \\
\hline & Benzene, 1,3-dimethyl- & & & 1.23 & & \\
\hline & $\begin{array}{c}\text { Benzene, } \\
\text { 1-isocyano-2-methyl- }\end{array}$ & & & 1.19 & & \\
\hline & $\begin{array}{c}\text { Benzene, } \\
\text { 1-ethyl-3-methyl- }\end{array}$ & & & & & 0.83 \\
\hline & $\begin{array}{c}\text { Benzene, } \\
\text { (2-methylcyclopropyl)- }\end{array}$ & & & & & 0.17 \\
\hline & Toluene & 1.13 & 6.37 & 7.62 & 9.00 & 10.73 \\
\hline & p-Xylene & 1.52 & 1.13 & & 1.98 & 2.77 \\
\hline & Ethylbenzene & & & & 1.57 & 2.66 \\
\hline & Styrene & & 0.88 & 0.84 & 1.87 & 4.06 \\
\hline & alpha.-Methylstyrene & & & & & 0.22 \\
\hline & sum & 2.65 & 8.38 & 11.61 & 16.12 & 28.44 \\
\hline \multirow{6}{*}{ Indenes } & Indene & & & & 0.93 & 1.57 \\
\hline & 1H-Indene, 1-methyl- & & & & & 1.38 \\
\hline & 2-Methylindene & & & & & 0.80 \\
\hline & 1H-Indene,2,3-dimethyl- & & & & & 0.19 \\
\hline & 1H-Indene, 4,7-dimethyl- & & & & & 0.24 \\
\hline & sum & 0 & 0 & 0 & 0.93 & 4.18 \\
\hline sum & & 2.65 & 8.38 & 11.61 & 17.05 & 32.62 \\
\hline
\end{tabular}

The thermal cracking products of sample also included some fatty acid compounds, mainly from the thermal cracking of lipid in sample ${ }^{[4]}$. Table 6 showed that the fatty acid compounds were mainly long chain fatty acids, and no fatty acid compounds were produced at low temperature of $350^{\circ} \mathrm{C}$; a very small amount of fatty acid compounds were detected until $450^{\circ} \mathrm{C}$; at the temperature range of $450^{\circ} \mathrm{C}-550^{\circ} \mathrm{C}$, the relative content of fatty acid compounds grew got a maximum of $5.59 \%$ at $550^{\circ} \mathrm{C}$; while at range of $550^{\circ} \mathrm{C}-750^{\circ} \mathrm{C}$, fatty acid compounds reduced.

There were also some nitrogen-containing compounds in the thermal cracking products of sample, which are mainly derived from the thermal cracking of proteins and chlorophyll in the body ${ }^{[18-20]}$. From Table 7 , it can be seen that the nitrogen-containing compounds were mainly composed of amides, pyrimidines, indoles and quinolines, which varied with increasing temperature. When temperature raised from $350^{\circ} \mathrm{C}$ to $450^{\circ} \mathrm{C}$, the relative content of the nitrogen-containing compounds gradually increased and reached a maximum of $11.31 \%$ at $450^{\circ} \mathrm{C}$; when the temperature raised to $550^{\circ} \mathrm{C}$ began to decline; when temperature continued to rise to $650^{\circ} \mathrm{C}$, the relative content of nitrogen compounds increased slightly.

Table 6 Effect of temperature on fatty acids from sample pyrolyzed at $350^{\circ} \mathrm{C}-750^{\circ} \mathrm{C}$

\begin{tabular}{|c|c|c|c|c|c|c|}
\hline \multirow{2}{*}{ Groups } & \multirow{2}{*}{ Compounds } & \multicolumn{5}{|c|}{ Peak area percentage/\% } \\
\hline & & $350^{\circ} \mathrm{C}$ & $450^{\circ} \mathrm{C}$ & $550^{\circ} \mathrm{C}$ & $650^{\circ} \mathrm{C}$ & $750^{\circ} \mathrm{C}$ \\
\hline \multirow{8}{*}{ Acids } & $\begin{array}{c}\text { Decanoic acid, } \\
\text { 10-(2-hexylcyclopropyl) }\end{array}$ & & & & & 0.20 \\
\hline & Myristoleic acid & & 0.32 & & & \\
\hline & Hexadecenoic acid, Z-11- & & & 1.07 & & \\
\hline & cis-13-Octadecenoic acid & & 0.38 & 1.33 & & \\
\hline & 6-Octadecenoic acid, (Z)- & & & 1.59 & 0.51 & \\
\hline & Octadec-9-enoic acid & & & & 0.60 & \\
\hline & 9-Octadecenoic acid, (E)- & & & 1.11 & & \\
\hline & Oleic Acid & & & 0.49 & 0.33 & \\
\hline sum & & 0 & 0.70 & 5.59 & 1.44 & 0.20 \\
\hline
\end{tabular}

Table 7 Effect of temperature on nitrogen compounds from sample pyrolyzed at $350^{\circ} \mathrm{C}-750^{\circ} \mathrm{C}$

\begin{tabular}{|c|c|c|c|c|c|c|}
\hline \multirow{2}{*}{ Groups } & \multirow{2}{*}{ Compounds } & \multicolumn{5}{|c|}{ Peak area percentage/\% } \\
\hline & & $350^{\circ} \mathrm{C}$ & $450^{\circ} \mathrm{C}$ & $550^{\circ} \mathrm{C}$ & $650^{\circ} \mathrm{C}$ & $750^{\circ} \mathrm{C}$ \\
\hline \multicolumn{7}{|c|}{ Nitrogen compounds } \\
\hline \multirow{6}{*}{ Amides } & Hexadecanamide & 3.14 & 3.44 & & 1.54 & \\
\hline & Octadecanamide & & & 2.75 & & \\
\hline & 9-Octadecenamide, (Z)- & 5.24 & & & & \\
\hline & Nonadecanamide & & & & 0.42 & \\
\hline & Benzyl nitrile & & 0.61 & & 1.86 & 2.60 \\
\hline & Hexadecanenitrile & & 0.87 & 1.00 & & \\
\hline \multirow{4}{*}{ Indoles } & Indole & & 4.25 & 2.20 & 2.81 & 2.56 \\
\hline & 1H-Indole, 3-methyl- & & 2.14 & 1.27 & 2.16 & 1.30 \\
\hline & 1H-Indole, 4-methyl- & & & 0.56 & 0.30 & 0.90 \\
\hline & $\begin{array}{c}\text { Indole, 3-[3-(4-morpholinyl) } \\
\text { prop-1-enyl]- }\end{array}$ & & & 0.15 & & \\
\hline \multirow{5}{*}{ Pyrimidines } & Pyridine & & & & 0.75 & 1.33 \\
\hline & Pyridine, 2-methyl- & & & & & 0.43 \\
\hline & Pyridine, 4-methyl- & & & & 0.33 & \\
\hline & $\begin{array}{c}\text { Pyridine-3-carboxamide, } \\
\text { oxime, N-(2- } \\
\text { trifluoromethylphenyl)- }\end{array}$ & & & & 0.18 & \\
\hline & $\begin{array}{c}\text { [1,2,4]Oxadiazole, } \\
\text { 3-(5-bromofuran-2-yl)- } \\
\text { 5-furan-2-yl- }\end{array}$ & & & & 0.28 & \\
\hline Quinolines & Quinoline & & & & & 0.81 \\
\hline sum & & 8.38 & 11.31 & 7.93 & 10.63 & 9.93 \\
\hline
\end{tabular}

In addition, sample also detected a number of polycyclic aromatic hydrocarbons (PAHs) that have been 
described as a typical pollutant which was listed in Table 8. At temperatures ranging from $350^{\circ} \mathrm{C}$ to $550^{\circ} \mathrm{C}$, the content of PAHs was almost the same as the cracking temperature raised. When temperature raised up to $550^{\circ} \mathrm{C}-750^{\circ} \mathrm{C}$ range, the relative content of PAHs increased rapidly from $1.11 \%$ to a maximum of $5.6 \%$, possibly due to the secondary reaction of the pyrolysis products at high temperature. Therefore, it is recommended to take a lower pyrolysis temperature to avoid the generation of PAHs.

Table 8 Effect of temperature on polycyclic aromatic hydrocarbons (PAHs) from sample pyrolyzed at $350^{\circ} \mathrm{C}-750^{\circ} \mathrm{C}$

\begin{tabular}{|c|c|c|c|c|c|c|}
\hline \multirow{2}{*}{ Groups } & \multirow{2}{*}{ Compounds } & \multicolumn{5}{|c|}{ Peak area percentage/\% } \\
\hline & & $350^{\circ} \mathrm{C}$ & $450^{\circ} \mathrm{C}$ & $550^{\circ} \mathrm{C}$ & $650^{\circ} \mathrm{C}$ & $750^{\circ} \mathrm{C}$ \\
\hline \multirow{10}{*}{ PAHs } & Naphthalene & & & & & 2.47 \\
\hline & Naphthalene, 1-methyl- & & & & & 1.80 \\
\hline & Naphthalene, 1,5-dimethyl- & & & & 0.33 & \\
\hline & Naphthalene, 1,6-dimethyl- & & & & 0.48 & \\
\hline & Naphthalene, 1,7-dimethyl- & & & & & 0.36 \\
\hline & Naphthalene, 2,3-dimethyl- & & & & & 0.87 \\
\hline & 1,4-Dihydronaphthalene & & & & 0.52 & \\
\hline & $\begin{array}{c}\text { 2-Naphthalenemethanol, } \\
\text { decahydro-5- } \\
\text { methylene-8-vinyl- }\end{array}$ & & 0.18 & & & \\
\hline & $\begin{array}{l}\text { Naphthalene, 1,2- } \\
\text { dihydro-1,1,6-trimethyl- }\end{array}$ & 0.75 & 0.83 & 0.56 & 0.39 & \\
\hline & $\begin{array}{l}\text { Naphthalene, 1,2,3,4- } \\
\text { tetrahydro-1,1,6-trimethyl- }\end{array}$ & 0.65 & 0.96 & 0.55 & 0.60 & 0.10 \\
\hline sum & & 1.40 & 1.97 & 1.11 & 2.32 & 5.60 \\
\hline
\end{tabular}

Thermal cracking products of sample also detected a number of ketones, aldehydes and alcohols compounds and a very small amount of phenols, furan compounds (Table 9). When temperature raised from $350^{\circ} \mathrm{C}$ to $550^{\circ} \mathrm{C}$, the relative contents of ketones, aldehydes and alcohols compounds increased with raising temperature and reached a maximum of $13.0 \%$ at $550^{\circ} \mathrm{C}$; when the temperature continued to rise, the relative content of ketones, aldehydes and alcohols compounds decreased. However, in the range of $350^{\circ} \mathrm{C}-650^{\circ} \mathrm{C}$, both phenols and furan compounds increased gradually with raising temperature and reached a maximum of $3.39 \%$ and $0.23 \%$ at $650^{\circ} \mathrm{C}$, respectively, and which began to decline as the temperature continued to rise.

Among the thermal cracking products of sample, aliphatic hydrocarbon compounds are natural constituent of fossil fuels and can provide energy during combustion $^{[18]}$; aromatic hydrocarbon compounds are an important fuel additive, which can improve the quality of fuels. Fatty acid compounds can produce fatty acid methyl esters, namely biodiesel, by the transesterification reaction under the action of catalyst ${ }^{[21]}$, which can also undergo a deoxygenation to produce long chain aliphatic hydrocarbons $^{[22]}$. Figures 3-6 depicted the sum of the relative amounts of these three compounds at different temperatures. The relative content of these three substances reached a maximum of $42.25 \%$ at $750^{\circ} \mathrm{C}$ and reached $32.07 \%$ at $650^{\circ} \mathrm{C}$, but $750^{\circ} \mathrm{C}$ could resulted in more contaminants produced, such as nitrogen compounds and PAHs (15.53\%), which account for $2.58 \%$ more than $650^{\circ} \mathrm{C}(12.95 \%)$. Thus, the optimum thermal cracking temperature for sample was $650^{\circ} \mathrm{C}$ based on lower levels of contaminant emissions and higher biofuel yields.

Table 9 Effects of temperature on ketones, alcohols, aldehydes, phenols and furans from sample pyrolyzed at $350^{\circ} \mathrm{C}-750^{\circ} \mathrm{C}$

\begin{tabular}{|c|c|c|c|c|c|c|}
\hline \multirow{2}{*}{ Groups } & \multirow{2}{*}{ Compounds } & \multicolumn{5}{|c|}{ Peak area percentage/\% } \\
\hline & & $350^{\circ} \mathrm{C}$ & $450^{\circ} \mathrm{C}$ & $550^{\circ} \mathrm{C}$ & $650^{\circ} \mathrm{C}$ & $750^{\circ} \mathrm{C}$ \\
\hline ketones & $\begin{array}{l}\text { 2-Cyclopenten-1-one, } \\
\text { 3-methyl- }\end{array}$ & & & & 0.23 & \\
\hline \multirow{13}{*}{ Alcohols } & $\begin{array}{c}\text { Ethanol, 2-(5-amino-6- } \\
\text { chloropyrimidin-4-ylamino) }\end{array}$ & & & 0.45 & & \\
\hline & $\begin{array}{c}\text { Cyclopentanemethanol, } \\
\text { 1-hydroxy-.alpha.,3, } \\
\text { 3-trimethyl-2- } \\
\text { (3-methyl-1,3-butadienyl)- }\end{array}$ & & & & & 0.20 \\
\hline & $\begin{array}{l}\text { Cyclohexanol, 5-methyl-2- } \\
\text { (1-methylethenyl)- }\end{array}$ & & 0.094 & & & \\
\hline & $\begin{array}{l}\text { 1-Dodecanol, } \\
\text { 3,7,11-trimethyl- }\end{array}$ & & & & 0.75 & \\
\hline & $\begin{array}{c}\text { 2,4,7,14-Tetramethyl-4- } \\
\text { vinyl-tricyclo } \\
\text { [5.4.3.0(1,8)]tetradecan-6-ol }\end{array}$ & 0.47 & & & & \\
\hline & Z-7-Pentadecenol & & & 0.12 & & \\
\hline & Z-9-Pentadecenol & & & 0.094 & & \\
\hline & 1,16-Hexadecanediol & & 0.26 & & & \\
\hline & $\begin{array}{c}\text { 6,10,14-Hexadecatrien-1-ol, } \\
\text { 3,7,11, } \\
\text { 15-tetramethyl-, [R-(E,E)]- }\end{array}$ & & 4.50 & & & \\
\hline & $\begin{array}{l}\text { Z,Z-10,12-Hexadecadien- } \\
\text { 1-ol acetate }\end{array}$ & & & & 0.35 & \\
\hline & 5,8,11-Heptadecatrien-1-ol & & & & 0.68 & \\
\hline & Phytol & 2.15 & 1.22 & & & \\
\hline & Geranylgeraniol & & & 11.54 & & \\
\hline \multirow{3}{*}{ Aldehydes } & Butanal, 3-methyl- & & 0.58 & & & \\
\hline & $\begin{array}{l}\text { Cyclopropaneoctanal, } \\
\text { 2-octyl- }\end{array}$ & & & 0.80 & 0.036 & \\
\hline & 7,11-Hexadecadienal & & 0.96 & & & \\
\hline sum & & 2.62 & 7.61 & 13.0 & 2.05 & 0.20 \\
\hline \multirow{2}{*}{ Phenols } & Phenol & & 1.00 & & & \\
\hline & Phenol, 4-methyl- & & & 1.06 & 3.39 & 2.66 \\
\hline sum & & 0 & 1.00 & 1.06 & 3.39 & 2.66 \\
\hline Furans & Furan, 2,5-dimethyl- & & & & 0.23 & 0.11 \\
\hline Sum & & 0 & 0 & 0 & 0.23 & 0.11 \\
\hline
\end{tabular}




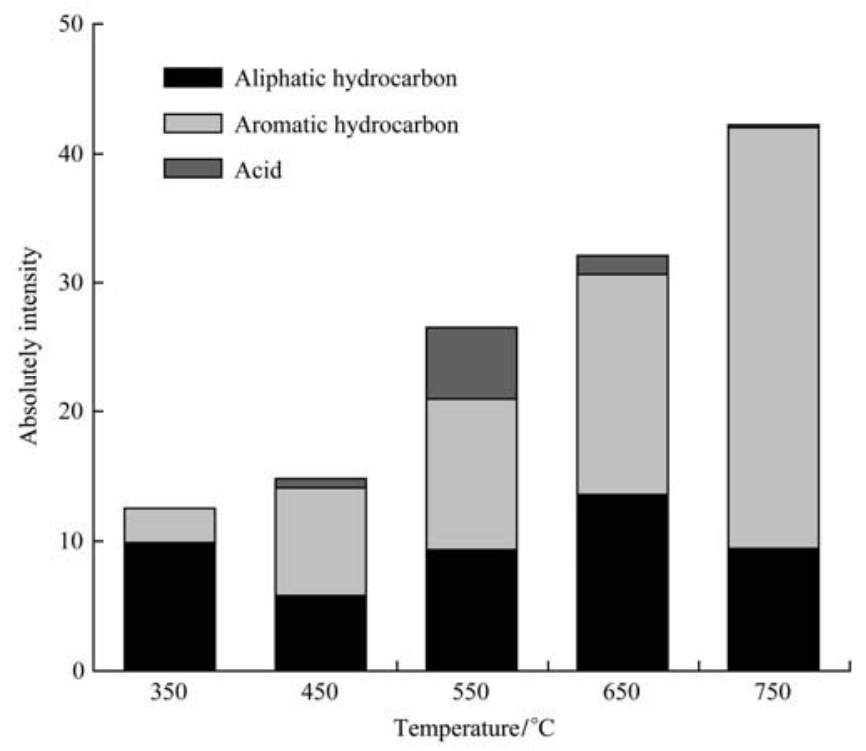

Figure 6 TIC diagram of sample pyrolytic bio-oil at $650^{\circ} \mathrm{C}$

\section{Conclusions}

Due to the higher carbon content (38.5\%) and relatively low nitrogen content (7.67\%) of sample, it can be concluded that the energy utilization potential of sample was huge. The thermal cracking products of sample were composed of aliphatic hydrocarbon compounds (alkanes and olefins), aromatic hydrocarbon compounds (benzene, indene and derivatives of both), fatty acids, nitrogen compounds, (indoles, pyrimidines and quinolines), polycyclic aromatic hydrocarbons (PAHs), ketones, aldehydes and alcohols, phenols and furan compounds. Temperature is an important factor affecting the composition of thermal cracking products of sample. Compared to bio-oil production at $650^{\circ} \mathrm{C}$ (32.07\%), sample pyrolyzed at $750^{\circ} \mathrm{C}$ could produce the highest bio-oil content of $42.25 \%$. However, higher temperature could lead to the formation of contaminants (nitrogen compounds and PAHs) more easily. Therefore, considering the higher content of bio-oil conversion and less pollutants generation, the optimum temperature for sample thermal cracking conversion was about $650^{\circ} \mathrm{C}$.

\section{Acknowledgments}

This research was supported by the Beijing Municipal Science and Technology Plan Projects (No. D161100006016001), and Beijing Municipal Key Discipline of Biomass Engineering.

\section{[References]}

[1] Li G, Ji F, Zhou Y, Dong R. Life cycle assessment of pyrolysis process of Desmodesmus sp. Int J Agric \& Biol Eng, 2015; 8(5): 105-112.

[2] Minowa T, Yokoyama S, Kishimoto M. Oil production from algal cells of Dunaliella tertiolecta by direct thermochemical liquefaction. Fuel, 1995; 74(12): 1735-1738.

[3] Demirbas A. Biomass resource facilities and biomass conversion processing for fuels and chemicals. Energy Convers Manag, 2001; 42: 1357-1378.

[4] Li G, Zhou Y, Ji F, Liu Y, Adhikari B, Tian L, et al. Yield and characteristics of pyrolysis products obtained from Schizochytrium limacinum under different temperature regimes. Energies, 2013; 6: 3339-3352.

[5] Rajagopal D, Zilberman D. Review of environmental, economic and policy aspects of biofuels. Policy Research Working Paper, No. wps 4341, 2007: 1-107.

[6] Demirbas A. Progress and recent trends in biofuels. Progress in Energy and Combustion Science, 2007; 33(1): $1-18$.

[7] Ginzburg B Z. Liquid fuel (oil) from halophilic algae: A renewable source of non-polluting energy. Renewable Energy, 1993; 3(2-3): 249-252.

[8] Zhou D, Zhang L, Zhang S C. Hydrothermal liquefaction of macroalgae Entermorpha prolifera to bio-oil. Energy Fuels, 2010; 24(7): 4054-4061.

[9] Ross A. B, Biller P, Kubacki M L, Li H, Lea-Langton A, Jones J M. Hydrothermal processing of microalgae using alkali and organic acids. Fuel, 2010; 89(9): 2234-2243.

[10] Bligh E, Dyer W J. A rapid method of total lipid extraction and purification. Can J Biochem Physiol, 1959; 37(8): 911-917.

[11] Rao Q, Labuza T P. Effect of moisture content on selected physicochemical properties of two commercial hen egg white powers. Food Chem, 2012; 132(1): 373-384.

[12] Mahinpey N, Murugan P, Mani T, Raina R. Analysis of bio-oil, biogas, and biochar from pressurized pyrolysis of wheat straw using a tubular reactor. Energy Fuels, 2009; 23(5): 2736-2742.

[13] Friedl A, Padouvas E, Rotter H, Varmuza K. Prediction of heating values of biomass fuel from elemental composition. Anal Chim Acta, 2005; 544(1): 191-198.

[14] Harman-Ware A E, Morgan T, Wilson M, Crocker M, Zhang $\mathrm{J}$, Liu K L, et al. Microalgae as a renewable fuel source: Fast pyrolysis of Scenedesmus sp. Renew. Energy, 2013; 60: 625-632.

[15] Greenhalf C E, Nowakowski D J, Bridgwater A V, Titiloye J, Yates N, Riche A, et al. Thermochemical characterisation of straws and high yielding perennial grasses. Ind Crop 
Prod, 2012; 26: 449-459.

[16] Li G, Dong R, Fu N, Zhou Y, Li D, Chen X. Characterization of pyrolysis products obtained from Desmodesmus sp. cultivated in anaerobic digested effluents (DADE). International Journal of Food Engineering, 2015; 11(6): 825-832.

[17] Li G, Dong R, Fu N, Zhou Y, Li D, Chen X. Temperature-oriented pyrolysis on the decomposition characteristic of Chlorella pyrenoidosa. International Journal of Food Engineering, 2016; 12(3): 295-301.

[18] Li R, Zhong Z, Jin B, Zheng A. Selection of temperature for bio-oil production from pyrolysis of algae from lake blooms. Energy Fuels, 2012; 26(5): 2996-3002.

[19] Thangalazhy-Gopakumar S, Adhikari S, Chattanathan S A,
Gupta R B. Catalytic pyrolysis of green algae for hydrocarbon production using $\mathrm{H}^{+} \mathrm{ZSM}-5$ catalyst. Bioresour Technol, 2012; 118: 150-157.

[20] Maddi B, Viamajala S, Varanasi S. Comparative study of pyrolysis of algal biomass from natural lake blooms with lignocellulosic biomass. Bioresour Technol, 2011; 102(23): 11018-11026.

[21] Wang L, Li Y, Chen P, Min M, Chen Y, Zhu J, et al. Anaerobic digested dairy manure as a nutrient supplement for cultivation of oil-rich green microalgae Chlorella sp. Bioresour Technol, 2010; 101: 2623-2628.

[22] Duan P, Savage P E. Catalytic treatment of crude algal bio-oil in supercritical water: optimization studies. Energy Environ Sci, 2011; 4(4): 1447-1456. 